\title{
Creativity and Innovation in Ecological Fashion*
}

\author{
Lorenzo Braccialini $^{* *}$
}

\begin{abstract}
Braccialini is one of the major Italian companies in the leather accessory field, symbol of the Italian entrepreneurship combined with know-how and imagination. In many countries, Braccialini brand stands for its authentic meaning of Made in Italy. However, Braccialini is also among the most modern companies deeply committed to the themes of environmental protection and sustainable development. In this paper, Braccialini Company will be presented by describing, in particular, its commitment toward a sustainable development.
\end{abstract}

Keywords: Luxury Fashion Management; Environmental Sustainability; Made in Italy; Leather Accessory Market; Braccialini

\section{Braccialini in the Leather Accessory Market}

Braccialini represents one of the major Italian enterprises in the leather accessory field, managing several trademarks, directly owned or under license agreement. It is an emblem of the Italian entrepreneurship combined with expertise and imagination; in many countries, Braccialini brand embodies the Made in Italy. Today, Braccialini is among the most modern companies deeply committed to the themes of environmental protection and sustainable development.

A sustainable development refers to the process for moving toward sustainability and implies trying to achieve a sustainable human future. Thus, a sustainable development includes economic, social, and environmental actions and our company is focused on all three aspects. From 2000 to 2010, Braccialini's turnover enjoyed an 8-fold increase, with an average $40 \%$ annual growth. These results were achieved by targeting our own trademarks and tying strategic alliances with international holdings. In 2014, the Group had $€ 65$ million revenues coming for $65 \%$ from foreign markets.

In this paper, I am going to present the Braccialini Company by focusing, in particular, on our actions toward a sustainable development.

\footnotetext{
* Invited Article

** Chief Marketing \& Communication Officer, Braccialini (info@braccialini.it)

Edited by: ISTEI - University of Milan-Bicocca ISSN: 1593-0319

Braccialini, L. (2015). Creativity and Innovation in Ecological Fashion, Symphonya. Emerging Issues in Management (symphonya.unimib.it), 4, 31-39.
} 


\section{Braccialini: Sixty Years of History, Creativity, Innovation, and Passion}

In 1954, Carla and Roberto Braccialini established their first leather workshop of bags. In 1976, Carla took the helm of the company after the premature death of her husband and she carried on her project with tenacious determination, ready to face future business challenges.

Four years later, Carla's sons, Riccardo and Massimo Braccialini step into the company. In 1987, the company signed a license agreement with Vivienne Westwood, the well-known British Maison, for the production and marketing of its trademarked accessories: bags, belts, and small leather items.

In 1988, on the wake of an initiative undertaken by Braccialini family, Contromano was established: a company specializing in medium target leather production. Over the course of the years, Contromano entered into license agreements with RoccoBarocco, Fiorucci, Bagutta, etc. By featuring a lower price line targeted to a younger and dynamic public, Braccialini launched a new accessories' collection with the trademark TUA by Braccialini. In 1991, Braccialini inaugurated its first boutique in Ischia and, in 1993, also a boutique in its own town, Florence. In 2000 the company tied up a strategic alliance with the Mariella Burani Fashion Group, which was already quoted on the stock exchange.

A new luxury hub was thus created and the company opened two mono-brand stores in Milan and Tokyo (at Ginza) in 2001. In 2002, the first brand-franchising project took off and the new holding company Antichi Pellettieri was established as a spin-off corporation in the leather sector, which gathered the Braccialini shares owned by the Burani Group.

The opening of new mono-brand stores continued at a breathtaking pace, together with the inauguration of a new showroom in Milan for the wholesale and retail buyers. The joining of the private French equity fund L Capital (LVMH Group) to the Antichi Pellettieri share capital, financed the growth of the Group's brands. In 2006, the company recorded a 25\% growth and confirmed its presence in 40 countries around the world. Three new mono-brand boutiques were inaugurated in Milan, Moscow, and Pusan (South Korea). It acquired 100\% stake of Dadorosa Srl, a worldwide licensee of the Florentine historical brand Gherardini. New stores were opened in Dubai, Paris, Forte dei Marmi, Varese, Moscow, and Kazan. Braccialini started a brand extension strategy, on its main brand Braccialini, by signing various license agreement in other segments: garments (t-shirts, scarves, beachwear), jewelry, perfumes and beauty products, helmets, and watches.

In 2008, a bigger showroom is inaugurated in Milan, at Corso Venezia 5, with a total surface of 600 square meters. The opening of 15 other mono-brand boutiques is on schedule and the first Braccialini fragrance is launched. In 2009, Carla Braccialini was nominated 'Cavaliere del Lavoro', the maximum acknowledgement assigned to those entrepreneurs who distinguished themselves in the economic world. In addition, a new Braccialini headquarter is inaugurated at Scandicci on the project of a Feng Shui inspired garden-Factory.

The company expansion in China starts and plans the opening of about 40 stores in the following four years with the first store openings in Shanghai, Chongqing and Chengdu. Moreover, three mono-brand boutiques are inaugurated in Rome 
(Galleria Colonna, Leonardo Da Vinci Airport, and Leonardo Park) and a first mono-brand outlet in Italy is opened in the space "The Mall".

A cooperation with WWF Italy starts for the Autumn-Winter collection and the brand Francesco Biasia is acquired. In 2011, the family organized a consortium of institutional investors to leave the Group and go back to financial independency. In 2014, the company celebrated 60 years with an exhibition at the Marino Marini Museum in Florence, during the 86th edition of Pitti Uomo.

\section{The Braccialini Multi-Brand Portfolio}

The Braccialini Group designs and produces eight product collections that are sold worldwide in over 70 countries. In fact, the initial international strategies that have been mapped out, led to a rapid expansion throughout Europe, Russia, Middle East, China, South Korea and Japan.

The core business of Braccialini focuses on handbags, small leather goods, and belts. The Group manages a multi-brand portfolio composed by both proprietary brands (Braccialini, Tua by Braccialini, I Temini by Braccialini, AmazonLife, and Francesco Biasia) and licensed brands (Gherardini, Vivienne Westwood, Ducati, and Ducati Scrambler). In fact, Braccialini is currently in partnership with some of the most prestigious and well-known brands worldwide and other new agreements are underway. The goal is to run the production and to increase overall sales, leveraging the company expertise and flexibility in order to create synergies and strategies that enhance the distribution.

Braccialini products are considered as unique and universal; these latter features represent two image profiles that come from the company's 'origins' to date. The brand uniqueness derives from its historically valuable DNA, which has made it contemporary in the style of its products, while the potential universality comes from the Made in Italy and artisan skill, the creative talent expressed in forms and materials, and the supreme care paid to details.

The values of the brand Braccialini, related to the concepts of contemporary creativity, originality, and flair, are proposed in the various product lines in an articulated manner so as to determine a specific brand positioning. For example, the main collection Braccialini is focused on glamour, urban daily life, versatility, well focused mix of colors, and current trends. Instead, the brand TUA by Braccialini is characterized by lightheartedness, a daily use, fantasy, artistic flair, and irony and storytelling.

Our objective is to place Braccialini brand in the highest tier of the luxury fashion market by responding to the needs and expectations of our target clients through a clear product definition and a broadened assortment of products. Our target market is represented by educated women, aged between 24 and 50, contemporary in taste and sensitive to originality, which enjoy unconventionality and are keen to use accessories enriching their look, especially those made with exclusive and distinctive details.

Besides strengthening the recognition of Braccialini brand through focused advertising campaigns, the company aims at expanding sales through the strategy of 
brand extensions, by introducing active licenses in new product categories such as shoes, umbrellas and fragrances.

\section{The Braccialini Boutiques Worldwide}

The Braccialini Group is keen on the opening of prestigious proprietary boutiques, together with a strenuous action aimed at establishing franchised monobrand points of sale and setting up corners and dedicated spaces in important retail shops inside the most renowned department stores worldwide. This fervent activity constantly projects Braccialini toward the expansion of the distribution network and further the development of our retail channel.

Since 1993, the year that marked the inauguration of our first boutique in Florence, the number of Braccialini shops has increased so much so that today the company is present nearly everywhere in the world. In 2002, it also embarked on a decisive franchising project: a winning distribution policy and sales philosophy led to the establishment of a widespread commercial network in Italy and in the world.

The "Together" multi-brand store is a neutral space that has been conceived to gather all brands owned by the Braccialini Group (Braccialini, Gherardini Francesco Biasia, and Amazonlife). The project design stems from a collaboration between Braccialini and Studio 63 and is aimed at creating a neutral yet highly identifiable space in its basic, refined, warm and contemporary look.

All Braccialini boutiques are consistent with the company's concept design: a minimalist and refined layout that is rich in prestigious materials. White is the dominant color for the walls that are in contrast with black glass partitions and mirrored spaces; the final result is an ideal ambience that welcomes the multicolored Braccialini world. To become a Braccialini franchisee means to profit from the company's expertise and finely tuned operational procedure and to exploit the synergy and strength, not just of a brand, but of a leading Group.

The Braccialini boutique-concept recalls an ideal environment thanks to the unusual artistic and emotional implications of the Braccialini product. A team of architects and specialized interior designers conceived new and original ideas for the setting up and preparation of the single brand retail stores worldwide, in harmony with the philosophy and image of the Braccialini brand. The network of Braccialini stores includes both direct stores (DOS) and franchisee stores in Europe, Asia, and the Americas. Through the franchising, the company aims at achieving a balanced development of the distribution network, a higher brand visibility both locally and internationally, and an operational growth.

There are three types of concept stores available through the franchising channel (from the deluxe flagship store to the more commercial single brand outlet), depending on the location and the market demand. Braccialini evaluates new potential affiliates' requests based on their geographical location, sales footage and customer base.

The 'Corner' and 'Shop-in-Shop' programs rotate around having the Braccialini logo and products inside multi-brand retail stores: the projects range from personalized corners to luxuriously furnished shop-in-shops. 


\section{Corporate Sustainability at Braccialini}

The Braccialini Group has always invested in pursuing environmental sustainability and sustainable development since it is our opinion that "ecology is an added value and being able to produce in a sustainable way is a luxury".

Our commitment toward environmental and social sustainability is articulated in different actions that the company realized over the years and is still realizing. Some of these actions are strictly related to the manufacturing of products or the protection of social and ecological environment through agreements with international organizations such as WWF. In particular, the brand Gherardini often supports the restauration of artistic and cultural pictures.

Today, Braccialini is among the most modern companies, deeply committed to the themes of environmental protection and sustainable development. A description of the main activities of social and environmental sustainability implemented at Braccialini follows.

\subsection{AmazonLife}

AmazonLife is a Brazilian trademark whose international license was acquired in July 2007 by Braccialini. It aims to defend the Amazonian traditions and cultures, which are often threatened and, consequently, need to be safeguarded through the promotion of a sustainable lifestyle, in perfect balance with the environment and its preservation.

By purchasing rubber - the raw material used for the manufacturing of the bags AmazonLife gives work to several families of rubber tappers - known in the local language as "Seringueiros", from the name of the rubber tree, the "Seringueira" who live in the area of Boca do Acre. These families spend six months every year in the heart of the darkness of Amazon rainforest, where they extract latex and process it by hand. The outcome of such hard and patient work is an authentic vegetable rubber, which represents a valid economic alternative for these people, as well as a precious instrument to safeguard territorial biodiversity and to prevent the merciless deforestation of the Amazon basin, the greatest lung of the American continent, which is about to collapse. We launched a new collection of bags and accessories using only natural, recycled and environmentally friendly materials.

AmazonLife's commitment to the production of environmentally friendly bags demonstrates that it is possible to extract resources and materials from nature, such as cotton, linen, jute, coconut, straw, and so on, without jeopardizing or damaging it, and on the contrary, to use them for making bags and accessories.

Besides relying on the use of natural raw materials, AmazonLife also recycles garments, shirts and old foulards to give life to a collection 'without frontiers' that brings forest lifestyle and respect for the environment into daily urban life. It is an expression of simplicity, purity and nature values addressed to all those who understand the meaning of a true style.

We believe that is a different and ethical way to be trendy, key element at the heart of our society, and pure oxygen for our modern way of thinking, a naturally glamorous and eco-chic style that chooses to embrace seriously the concepts of ecology, sustainability and the utilization of renewable sources. Amazonlife proves 
that it is possible to harmoniously utilize materials and resources that the nature offers us, such as cotton, linen, jute, coconut, straw and more, to produce fashion accessories. This goal is achieved through a direct collaboration of the Indios by offering viable economic and labor alternatives to local populations.

\subsection{Braccialini for Africa}

Braccialini's support to the Busajo non-governmental organization (NGO) contributed to realize an artesian well, an essential initial step for the building of a new structure where to receive the street children of Soddo, in Ethiopian Wolayta region, one of the Africa's most underprivileged areas. Street children are orphaned, abandoned or rejected by their families and they have no title to long distance adoptions, so they cannot access schooling, medical care or job training programs. The Busajo NGO censed over 2000 street children in Soddo and manages a large reception and re-education center dedicated to them since 2009. In 2013 , it planned to build a new structure to face the ever increasing number of abandoned kids in that area. Braccialini supported the charity project in cooperation with Busajo Onlus by donating the revenues of the "smile bag" that was an item of the spring-summer 2013 collection.

\subsection{Braccialini for WWF Italy Projects}

Braccialini's environmentally friendly bags made using only raw materials with zero-impact, support the WWF Italy's campaign by devoting the revenue from the sale of three of the handbags from the new collection to this initiative. The three exclusive models created for WWF were manufactured with the hemp obtained from old canvas cots of the Amerigo Vespucci training ship and rubberized canvas of army ponchos, while finishes are in natural rubber. Furthermore, the Braccialini Winter Collection 2010/2011 supported the project "Save the animals!" by abandoning the city for an ironic celebration of the nature.

In the past, the company launched the "Royal Owl" inspired bags in the Braccialini A/W 2007/2008 Collection, in order to alert public opinion about the risk of extinction faced by this majestic bird of prey, whose number has reduced to two thirds over the last hundred years. By recognizing this environmental problem, Braccialini contributed to the protection of the "Prince of the Night" with a significant donation to the Mugello Bird of Prey Recovery Center.

\subsection{Charity for Japan}

Braccialini supports the victims of the earthquake in Japan, country with whom the Florentine company has collaborated for 30 years and where both Braccialini and Gherardini have always scored a great success. Conceived as an act of love toward the Land of the Rising Sun, the "We Love Japan" bag borrows some of the most cherished and famous symbols of Japan (from the Tree of Life to geisha's fans) to give life to a super colorful, playful landscape with Mt. Fuji in the background. A true celebration of life and creativity in line with the Braccialini tradition. 
Only 150 examples of this model were produced; a red sun shining on a white background: patterns and colors from the Japanese flag characterize the new "Gherardini for Japan" shopping bag. Six hundred pieces in limited edition were produced, sold in Japan, in Gherardini corners, and in Gherardini mono-brand boutiques in Italy, and all revenues from sales were donated to the Japanese Red Cross.

\subsection{Cartoline for UNESCO}

Braccialini has also become a spokesperson for the values promoted by UNESCO. To this end, the Cartoline (Postcards) product line, that was part of the Tua by Braccialini Autumn/Winter 2008-2009 collection, featured a series of five bags depicting images from some of the places recognized as a World Heritage by UNESCO.

Through this initiative, Braccialini donated part of the sales' earnings of these bags to the Italian Commission for UNESCO, in order to give a concrete contribution to the preservation of these natural and cultural sites of exceptional importance.

UNESCO devolved the funds donated by Braccialini to the UNESCO Week of Education for Sustainable Development, whose third edition took place in November 2009 on the issue of city and active citizenship. This event was addressed primarily to local communities, city governments and private enterprises in order to develop operational capabilities and raise awareness on the issues relating to the construction of an environmentally friendly and solidarity-based 'city', grounded on new lifestyles that pivot on the concepts of accountability and active participation.

\subsection{Gherardini at the support of the Art}

Gherardini brand launched a line of bags inspired to Leonardo's drawing by using precious materials, such as embroidered calfskin and braided leather tapes. The numbered pieces of Monna Rosa (digitally elaborated and printed on canvas of the enigmatic Gioconda) and Monna Story (hand painted by the artist Giacomo Piussi) were distributed in the mono-brand boutiques of Florence, Milan and Rome. They were made entirely by hand in testimony to the excellence of the Made in Italy artisanship that has always distinguished Gherardini's creations. With the sale revenues, Gherardini financed an intervention of restoration of a painting in Florence located inside the Palazzo Medici Riccardi museum (already residence of Lorenzo the Magnific).

The Pretiosa handbag represents a unique, elegant and contemporary accessory that finds its roots in the Renaissance; its name expresses the great value that is intrinsic in the bag, based on a 15th century sketch by Leonardo Da Vinci. It was conceived as an homage both to the city of Florence, where the Gherardini house was established 126 years ago, and to Leonardo, who turned Lisa Gherardini's portrait into one of the most famous and studied paintings of all times: the Gioconda. 


\subsection{The Ultra-Modern Head Quarters of Scandicci}

In 2009, the traditional Braccialini site was restored in order to accommodate more than 200 employees in an environment that improves the quality of work and wellbeing. The new building rose on the remains of an antique Florentine foundry (in the former Le Cure area), in the heart of Italy's most important leather manufacturing district.

The project was originally conceived by the architect Turchi, on an initial request for a low environmental impact by the municipality of Scandicci. Then the project was developed by the architect Sandro Cammilli, and foresees a cement structure with minimal, technologically advanced finishing. It is inspired to Feng Shui principles, the ancient Taoist geomantic art of China, with a garden-factory of 11,200 square meter surface. The element of major impact is surely represented by the principle façade, covered entirely by a vertical garden with plants and ivy that witness to an aesthetic choice hinging on a strong vision of environmental defense. Beyond reducing the external noise pollution that can reach 18 decibels, the wall garden has also the function of stabilizing the temperature of the wall exposed to the sun, possibly reducing by some degrees, with consequent reduction of energy consumption. In fact, the project foresaw the use of renewable sources of energy like photovoltaic solar panels and the recovery of rainwater for irrigation of the garden.

The attention to an external environmental impact is accompanied by a care to the quality of work, 'livability' and mental wellbeing. These represent the three key principles that Braccialini wanted to follow when commissioned the project for the new site. This intervention not only has recovered the Scandicci area, which was into decline, but has contributed to strengthen the industrial profile of the town with positive effects on the local community.

\section{Bibliography}

Arnold, Mark J. \& Kristy E. Reynolds (2003) Hedonic Shopping Motivations, Journal of Retailing, 79 (2), 77-95. http://dx.doi.org/10.1016/S0022-4359(03)00007-1

Arrigo, E. (2011). Fashion, Luxury and Design: Store Brand Management and Global Cities' Identity, Symphonya. Emerging Issues in Management (symphonya.unimib.it), 1, 55-67. http://dx.doi.org/10.4468/2011.1.06arrigo

Brondoni, S.M. (2014). Global Capitalism and Sustainable Growth. From Global Products to Network Globalisation, Symphonya. Emerging Issues in Management (symphonya.unimib.it), 1, 10-31.

http://dx.doi.org/10.4468/2014.1.02brondoni

Brondoni, S.M. (2015). Global Networks, Outside-In Capabilities and Smart Innovation, Symphonya. Emerging Issues in Management (symphonya.unimib.it), 1, 6-21. http://dx.doi.org/10.4468/2015.1.02brondoni

Caniato, F., Caridi, M., Crippa, L., \& Moretto, A. (2012). Environmental sustainability in fashion supply chains: An exploratory case based research. International Journal of Production Economics, 135(2), 659-670. 
http://dx.doi.org/10.1016/j.ijpe.2011.06.001

Choi, H., Ko, E., Kim, E. Y., \& Mattila, P. (2015). The role of fashion brand authenticity in product management: A holistic marketing approach. Journal of Product Innovation Management, 32(2), 233-242.

http://dx.doi.org/10.1111/jpim.12175

Choi, T.M., Lo, C.K.Y, Wong C.W.Y., Yee R.W.Y. (2012). Green manufacturing and distribution in the fashion and apparel industries, International Journal of Production Economics, 135(2). http://dx.doi.org/10.1016/j.ijpe.2011.07.012

De Angelis, M., Adigüzel, F., \& Amatulli, C. (2017). The role of design similarity in consumers' evaluation of new green products: An investigation of luxury fashion brands. Journal of Cleaner Production, 141, 1515-1527.

http://dx.doi.org/10.1016/j.jclepro.2016.09.230

D'Souza, C. (2015). Marketing Challenges for an Eco-Fashion Brand: A Case Study. Fashion Theory, 19(1), 67-82.

http://dx.doi.org/10.2752/175174115X14113933306824

Freise, M., Seuring, S. (2015). Social and environmental risk management in supply chains: a survey in the clothing industry, Logistics Research, 8(1).

http://dx.doi.org/10.1007/s12159-015-0121-8

Gardetti, M.A., \& Torres A.L. (Eds.) (2014). Sustainability Luxury: Managing Social and Environmental Performance in Iconic Brands, Greenleaf Publishing, Sheffield.

Gnecchi, F. (2005). Brand Portofolio and Over-Supply. Symphonya. Emerging Issues in

Management (symphonya.unimib.it), 1, 56-65

http://dx.doi.org/10.4468/2005.1.05gnecchi

Kim, H.-S., \& Hall, M.L. (2015). Green brand strategies in the fashion industry: Leveraging connections of the consumer, brand, and environmental sustainability, Sustainable Fashion Supply Chain Management: From Sourcing to Retailing, 31-45.

http://dx.doi.org/10.1007/978-3-319-12703-3_2

Mosca, F., Tamborrini, P., \& Casalegno, C. (2015). Systemic Design: How to Compete by Leveraging the Value System, Symphonya. Emerging Issues in Management (symphonya.unimib.it), 2, 42-56.

http://dx.doi.org/10.4468/2015.2.04mosca.tamborrini.casalegno

Riboldazzi, S. (2005). Global Retailers and Competitive Customer Value, Symphonya. Emerging Issues in Management (symphonya.unimib.it), 2, 77-87.

http://dx.doi.org/10.4468/2005.2.07riboldazzi

Ryding, D., Navrozidou, A., \& Carey, R. (2014). The impact of eco-fashion strategies on male shoppers' perceptions of brand image and loyalty. International Journal of Business and Globalisation, 13(2), 173-196.

http://dx.doi.org/10.1504/IJBG.2014.064133

Salvioni, D.M., \& Bosetti, L. (2014). Sustainable Development and Corporate Communication in Global Markets, Symphonya. Emerging Issues in Management (symphonya.unimib.it), 1, 32-51.

http://dx.doi.org/10.4468/2014.1.03salvioni.bosetti

Theng So, J., Grant Parsons, A., \& Yap, S. F. (2013). Corporate branding, emotional attachment and brand loyalty: the case of luxury fashion branding. Journal of Fashion Marketing and Management: An International Journal, 17(4), 403-423.

http://dx.doi.org/10.1108/JFMM-03-2013-0032 